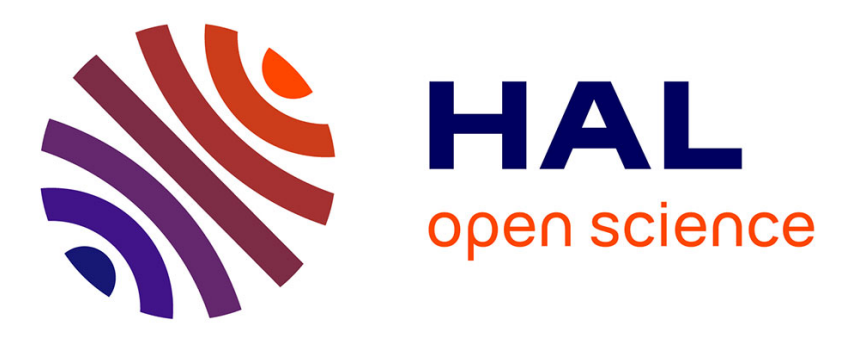

\title{
NVP-BEZ235, a dual PI3K/mTOR inhibitor, inhibits osteosarcoma cell proliferation and tumor development in vivo with an improved survival rate
}

Bérengère Gobin, Séverine Battaglia, Rachel Lanel, Julie Chesneau, Jérôme Amiaud, Françoise Rédini, Benjamin Ory, Dominique Heymann

\section{To cite this version:}

Bérengère Gobin, Séverine Battaglia, Rachel Lanel, Julie Chesneau, Jérôme Amiaud, et al.. NVPBEZ235, a dual PI3K/mTOR inhibitor, inhibits osteosarcoma cell proliferation and tumor development in vivo with an improved survival rate. Cancer Letters, 2014, 344 (2), pp.291 - 298. 10.1016/j.canlet.2013.11.017 . inserm-01644806

\section{HAL Id: inserm-01644806 https://www.hal.inserm.fr/inserm-01644806}

Submitted on 22 Nov 2017

HAL is a multi-disciplinary open access archive for the deposit and dissemination of scientific research documents, whether they are published or not. The documents may come from teaching and research institutions in France or abroad, or from public or private research centers.
L'archive ouverte pluridisciplinaire HAL, est destinée au dépôt et à la diffusion de documents scientifiques de niveau recherche, publiés ou non, émanant des établissements d'enseignement et de recherche français ou étrangers, des laboratoires publics ou privés. 
NVP-BEZ235, a dual PI3K/mTOR inhibitor, inhibits osteosarcoma cell proliferation and tumor development in vivo with an improved survival rate

Bérengère Gobin $\mathrm{MS}^{1,2}$, Séverine Battaglia $\mathrm{BSc}^{1,2}$, Rachel Lanel $\mathrm{BSc}^{1,2}$, Julie Chesneau $\mathrm{BSc}^{1,2}$, Jérôme Amiaud BSc ${ }^{1,2}$, Françoise Rédini $\mathrm{PhD}^{1,2,3}$, Benjamin Ory $\mathrm{PhD}^{1,2}$, Dominique Heymann $\mathrm{PhD}^{1,2,3}$

${ }^{1}$ INSERM, UMR 957, Equipe LIGUE Nationale Contre le Cancer 2012, Nantes 44035, France ${ }^{2}$ Université de Nantes, Nantes atlantique universités, Pathophysiology of Bone Resorption and Therapy of Primary Bone Tumors, Nantes, France

${ }^{3} \mathrm{CHU}$ de Nantes, France

Running title: NVP-BEZ235 to cure osteosarcoma

*Corresponding author:

Prof. Dominique Heymann

INSERM UMR 957, Faculty of Medicine,

1 rue Gaston Veil, 44035 Nantes cedex, France

Phone: 33 (0) 272641 132; Fax: 33 (0) 240412860

E-mail: dominique.heymann@univ-nantes.fr 


\begin{abstract}
Despite recent improvements in chemotherapy and surgery, the problem of non-response osteosarcoma to chemotherapy remains, and is a parameter that is critical for prognosis. The present work investigated the therapeutic value of NVP-BEZ235, a dual class I PI3K/mTOR inhibitor. NVP-BEZ235 inhibited osteosarcoma cell proliferation by inducing G0/G1 cell cycle arrest with no caspase activation. In murine pre-clinical models, NVP-BEZ235 significantly slowed down tumor progression and ectopic tumor bone formation with decreased numbers of $\mathrm{Ki}^{+}$cells and reduced tumor vasculature. Finally, NVP-BEZ235 considerably improved the survival rate of mice with osteosarcoma. Taken together, the results of the present work show that NVP-BEZ235 exhibits therapeutic interest in osteosarcoma and may be a promising adjuvant drug for bone sarcomas.
\end{abstract}

Key words: PI3K inhibitor, mTOR inhibitor, survival rate, pre-clinical model, osteosarcoma 


\section{INTRODUCTION}

Primary bone tumors are part of a large family of bone tumors including malignant and benign entities [1]. Bone sarcomas are malignant primary bone tumors with a common cellular origin. Osteosarcoma, which is the most frequent malignant bone tumor, originates from mesenchymal stem cells and has a common origin with Ewing's sarcoma and chondrosarcoma $[1,2]$. The current standard therapeutic approach to osteosarcoma is based on preoperative chemotherapy with a cocktail of 3 to 4 drugs (generally adriamycin, platinumrelated drugs and methotrexate) followed by delayed en-bloc wide resection for histologic assessment. After preoperative chemotherapy, patients are categorized as good and poor responders depending on the residual tumor cells in the resected tumor tissue [3]. This protocol was initially proposed by Rosen et al. at the end of the 1980s and made it possible to improve patient life expectancy and to avoid amputation of the limb in question [4]. Despite recent improvements in surgery and the development of different regimens of multi-drug chemotherapy over the last 3 decades, the long-term survival rate remains around $55-70 \%$ at 5 years according to published series $[5,6]$.

Unfortunately, the natural history of osteosarcoma is still mostly unknown, despite the fact that considerable efforts have been made by the medical community to identify new biomarkers that will be used to predict the therapeutic response of patients prior to the initiation of therapy or to adapt the drug regimen in case of recurrent disease [7]. Nevertheless, in the last few years, various therapeutic targets have been suggested and are at the origin of customized therapies [8,9]. Drugs against protagonists of signaling pathways have been developed extensively and entered very quickly into clinical trials. Almost cell signaling induced by cytokines/growth factors involves the PI3K/mTOR pathway, small synthetic inhibitors of these targets have been produced [10-13]. However, resistance 
mechanisms to mTOR inhibitors and the high frequency for mutation and/or gain in function of PI3K catalytic subunits in cancer cells has led to the development of dual PI3K/mTOR inhibitors such as NVP-BEZ235 [14]. NVP-BEZ235 is an imidazol[4,5]quinolone derivative which specifically targets the ATP-binding sites of PI3K and mTOR enzymes. Although NVP-BEZ235 has shown promising therapeutic activity in carcinomas $[15,16]$ and lymphomas [17], only a few reports are available for bone sarcomas [18,19], and, more specifically, osteosarcomas. For this report, the efficiency of NVP-BEZ235 was studied in vitro in 4 human and murine cell lines and in two models (syngenic and xenogenic) of osteosarcoma where tumor growth, bone histomorphometry and histology were assessed. 


\section{MATERIALS AND METHODS}

\subsection{Reagent}

NVP-BEZ235 was kindly provided by Pharma Novartis (Basel, Switzerland). Stock solution $(10 \mathrm{mM})$ was prepared in $100 \%$ of DMSO for the in vitro experiments. For mice, NVPBEZ235 was dissolved in $10 \%$ of 1-Methyl-2-pyrrolidinone (NMP; Sigma) $+90 \%$ of PEG300 (Sigma).

\subsection{Cell lines and culture conditions}

Human osteosarcoma MG-63 and HOS-MNNG (HOS) cells purchased from ATCC (USA) and rat osteosarcoma OSRGA cells [20] were cultured in DMEM (Lonza, Belgium) supplemented with 5\% of Fetal Bovine Serum (FBS; Hyclone Perbio, France). Murine osteosarcoma POS-1 and MOS-J cells were provided by Drs Kamijo [21] and Shultz [22] respectively and cultured in RPMI (Lonza, Belgium) supplemented with 5\% of FBS.

\subsection{Cell growth and viability}

Two thousand cells were seeded into 96-well plates and cultured for 72 hours with or without NVP-BEZ235 ( 1 to $200 \mathrm{nmol} / \mathrm{L}$ ). Cell growth and viability were determined by a colorimetric assay using the XTT reagent assay kit (Roche Molecular Biochemicals, Germany). Cell viability was also determined by means of trypan blue exclusion assay; viable and non-viable cells were counted manually after 24 and 48 hours of treatment.

\subsection{Caspase activity}

Two hundred thousand cells were seeded in 6-well plates and cultured with or without NVPBEZ235 for 3 to 48 hours $(25 \mu \mathrm{M})$. Caspase activity was assessed on $10 \mu 1$ of whole cell lysates using the CaspACE Assay System kit (Promega), in accordance with the 
manufacturer's recommendations. The results were expressed in arbitrary units, and corrected for protein concentration quantified by Bicinchoninic acid assay (Sigma). The lysate of cells treated with $1 \mu \mathrm{g} / \mathrm{ml}$ of Staurosporine (Invitrogen) overnight was used as the positive control.

\subsection{Cell cycle analysis}

Subconfluent cultures were incubated with or without $200 \mathrm{nM}$ of NVP-BEZ235 for 24 hours, trypsinized, washed and incubated in PBS containing $0.12 \%$ of Triton $\mathrm{X}-100,0.12 \mathrm{mM}$ of EDTA and $100 \mu \mathrm{g} / \mathrm{ml}$ of ribonuclease A DNase-free (Sigma). Then, $50 \mu \mathrm{g} / \mathrm{ml}$ of Propidium Iodide (IP; Promega) were added for 20 minutes. Cell cycle distribution was determined by means of flow cytometry (Cytomics FC500; Beckman Coulter), based on 2N and 4N DNA content, and analyzed using DNA Cell Cycle Analysis Software (Phoenix Flow System, San Diego, CA, USA).

\subsection{Cell signaling analysis}

Two hundred thousand cells were treated with 50-1000 nM of NVP-BEZ235 for 3 hours or with $200 \mathrm{nM}$ NVP-BEZ235 for 1 to 24 hours and then lysed in RIPA buffer $(150 \mathrm{mmol} / \mathrm{L}$ of $\mathrm{NaCl}, 5 \%$ of Tris, $\mathrm{pH} 7.4,1 \%$ of $\mathrm{NP}-40,0.25 \%$ of sodium deoxycholate, $1 \mathrm{mmol} / \mathrm{L}$ of $\mathrm{Na}_{3} \mathrm{VO}_{4}, 0.5 \mathrm{mmol} / \mathrm{L}$ of PMSF, $10 \mathrm{mg} / \mathrm{mL}$ of leupeptin, and $10 \mathrm{mg} / \mathrm{mL}$ of aprotinin). Lysates were cleared of debris by centrifugation at $12,000 \times g$ for 10 minutes. Total cell lysate (40 $\mu \mathrm{g}$ ), determined using the BCA kit, was run on $10 \%$ of SDS-PAGE and electrophoretically transferred to Immobilon-P membranes (Millipore). The membrane was blotted with antibodies (Supplementary Table 1) in PBS, $0.05 \%$ of Tween 20 , and $3 \%$ of BSA. The membrane was probed with the secondary antibody coupled to horseradish peroxidase. Antibody binding was visualized with the enhanced chemiluminescence system (Roche Molecular Biomedicals). 


\subsection{In vivo experiments: mouse models of osteosarcoma}

Mice (Elevages Janvier) were housed in pathogen-free conditions at the Experimental Therapy Unit (Faculty of Medicine, Nantes) in accordance with the institutional guidelines of the French Ethical Committee and under the supervision of authorized investigators. Two groups of $8 \mathrm{C} 57 \mathrm{Bl} / 6 \mathrm{~J}$ and two groups of $8 \mathrm{Rj}: \mathrm{NMRI}$-nude mice were assigned randomly to receive either placebo [oral administration of NMP-PEG (0.1\%)] or NVP-BEZ235 (oral administration, $45 \mathrm{mg} / \mathrm{kg} /$ day).

2.7.1 Syngenic model of osteoblastic osteosarcoma: Five-week-old male C57B1/6J mice were anesthetized by inhalation of an isoflurane/air mixture $(2 \%, 1 \mathrm{~L} / \mathrm{min})$ before receiving an i.m. injection of $1 \times 10^{6}$ mouse MOS-J osteosarcoma cells in close proximity to the tibiae, rapidly leading to tumor growth in the soft tissue with secondary contiguous bone invasion. Tumors appeared at the injection site 8 days later and led to osteoblastic lesions reproducing the osteoblastic form of human osteosarcoma [23].

2.7.2 Xenogenic model of osteoblastic osteosarcoma: Five-week-old female Rj:NMRI-nude mice were anesthetized as previously described before an i.m. inoculation of $2 \times 10^{6}$ human HOS osteosarcoma cells.

The mice were sacrificed by cervical dislocation for ethical reasons when the tumor volume reached $2000 \mathrm{~mm}^{3}$. For both models, tumor volumes were calculated by measuring two perpendicular diameters using calipers, according to the following formula: $\mathrm{V}=0.5 \mathrm{xLx}(\mathrm{S})^{2}$, in which $\mathrm{L}$ and $\mathrm{S}$ are, respectively, the largest and the smallest perpendicular diameters as previously described [23]. The bone microarchitecture was analyzed using the high-resolution X-ray micro-computed tomography $(\mu \mathrm{CT})$ system for small animal imaging Sky-Scan-1076 (SkyScan, Belgium). Analyses were performed at necropsy (tumor volume $2000 \mathrm{~mm}^{3}$, according with the recommendations of the Ethical Committee). All tibiae were scanned using the same parameters (pixel size $18 \mu \mathrm{m}, 50 \mathrm{kV}, 0.5 \mathrm{~mm}$ aluminum filter and 0.8 degree of 
rotation step). Three-dimensional reconstructions were made using CTvox software (Skyscan). Two-dimensional analyses of the bone parameters were performed on 200 layers (cortical aera) using the CTan software (Skyscan). Analysis of the specimens involved the following bone measurements: tissue volume $\left(\mathrm{TV}, \mathrm{mm}^{3}\right)$, bone volume $\left(\mathrm{BV}, \mathrm{mm}^{3}\right)$, percentage of bone volume (BV/TV, \%), tissue surface $\left(\mathrm{TS}, \mathrm{mm}^{2}\right)$, bone surface $\left(\mathrm{BS}, \mathrm{mm}^{2}\right)$, bone surface/bone volume ratio $\left(\mathrm{BS} / \mathrm{BV}, \mathrm{mm}^{-1}\right)$, bone surface density $\left(\mathrm{BS} / \mathrm{TV}, \mathrm{mm}^{-1}\right)$, trabecular spaces (TbSp, mm) and cortical or trabecular thickness (CTh, TbTh, mm).

\subsection{Bone histology and immunohistochemistry}

After euthanasia, the tibiae were preserved and fixed in $10 \%$ of PFA, decalcified with $13 \%$ of EDTA, and $0.2 \%$ of PFA in PBS using a microwave tissue processor (KOS, Mikron Instruments, USA) for 5 to 7 days and embedded in paraffin. $3 \mu \mathrm{m}$ sections were cut and stained using the Masson-trichrome method [23]. For TRAP staining, serial $4 \mu \mathrm{m}$-thick sagittal sections were prepared and stained to identify osteoclasts following1hour of incubation in a solution composed of $1 \mathrm{mg} / \mathrm{mL}$ of naphthol AS-TR phosphate, $60 \mathrm{mM}$ of NNdimethylformamide, $100 \mathrm{mM}$ of sodium tartrate, and $1 \mathrm{mg} / \mathrm{mL}$ of Fast red TR salt solution (Sigma) [24]. The staining surface was quantified using ImageJ (NIH, USA). Immunohistochemistry was carried out on 3mm-thick deparaffinized sections as described previously. The sections were incubated with diluted goat corresponding primary antibody (Supplementary data 1) for 1 hour. Positive immunostaining was quantified using Qwin software (Leica).

\subsection{Statistical Analysis}

Each experiment was repeated independently 3 times. The results are given as a mean \pm standard deviation (SD) (in vitro experiments) and mean \pm SEM (in vivo experiments) and 
were compared using the Unpaired t test or ANOVA followed by the Bonferroni post test using Graph Pad InStat v3.02 software. Results with $\mathrm{p}<0.05$ were considered significant. 


\section{RESULTS}

\subsection{NVP-BEZ235 is a powerful drug that inhibits the proliferation of osteosarcoma cells}

We first assessed the ability of NVP-BEZ235 (Figure 1A) to modulate the signaling pathway in osteosarcoma cells. As expected, NVP-BEZ235 considerably decreased the levels of both AKT and mTOR phosphorylation in a dose- (Figure 1B) and time-dependent (Figure 1C) manner in all the cell lines assessed, thus confirming the functional activity of NVP-BEZ235 on osteosarcoma cells. We then performed an XTT assay and manual counting of viable cells to determine the effects of NVP-BEZ235 on cell growth (Figure 1D). After 72 hours of treatment, and in a dose-dependent manner, NVP-BEZ235 had significantly inhibited the growth of all the cell lines tested with an $\mathrm{IC}_{50}$ ranging from 8 to $38 \mu \mathrm{M}$ and $\mathrm{IC}_{90}$ from 44 to 98 $\mu \mathrm{M}$ at 72 hours (Supplementary Table 2). In addition, manual counting of viable cells revealed that NVP-BEZ235 had significantly decreased the number of viable cells without inducing apoptotic cell death (data not shown). Flow cytometry investigations revealed that $200 \mathrm{nM}$ of NVP-BEZ235 increased cell numbers in the G0/G1 phase in human (Figure 2A) and murine (Figure 2B) osteosarcoma cell lines without the appearance of cells in the subG0 phase. Overall, these data revealed the inhibitory effect on osteosarcoma cell proliferation with no induction of cell death, as confirmed by the absence of caspase activation in the presence of the drug (Figures 2C and 2D).

\subsection{NVP-BEZ235 has anti-tumor activity in a murine syngenic osteosarcoma model}

Based on the inhibitory activity of NVP-BEZ235 on the proliferation of osteosarcoma cell lines, the biological activity of the drug was then assessed in vivo in a murine syngenic model of osteosarcoma. Figure 3 clearly shows that NVP-BEZ235 decreased tumor volumes compared to the control group (Figure $3 \mathrm{~A}, \mathrm{p}<0.01$ ) and slowed down the relative tumor 
progression between days 9 and 22 (Figure 3B, p<0.01). Micro CT analyses performed on tibiae with tumors revealed that NVP-BEZ235 had considerably and qualitatively reduced the ectopic bone formation deposited by the tumor cells (Figure 3C). This qualitative observation was confirmed by histomorphometry which showed a significant decrease in the BS $(\mathrm{p}<0.001)$ and BV $(\mathrm{p}<0.01)$ of the tumor ectopic bone formed with $45 \mathrm{mg} / \mathrm{kg} /$ day NVPBEZ235 compared to the control group (Figure 3D).

\subsection{NVP-BEZ235 slows down osteosarcoma growth in a xenogenic model and increases} the survival rate

The therapeutic value of NVP-BEZ235 was analyzed in a xenogenic model of osteosarcoma. As in the previous model, NVP-BEZ235 significantly reduced the tumor volume compared to the control group (Figure 4A, $<<0.01$ ) and slowed down tumor progression (Figure 4B, $\mathrm{p}<0.01)$. Relative tumor progression was $1260 \pm 204 \mathrm{~mm}^{3}$ for the control compared to $569 \pm$ $53 \mathrm{~mm}^{3}$ for the treated group. MicroCT investigations confirmed the inhibitory activity of NVP-BEZ235 on the formation of ectopic tumor bone compared to the control (Figure 4C). Thus, the BS decreased significantly from $64.88 \pm 5.61$ to $41.46 \pm 1.21 \mathrm{~mm}^{2}(\mathrm{p}<0.01)$ with 45 $\mathrm{mg} / \mathrm{kg} /$ day NVP-BEZ235 compared to the untreated group and the BV decreased in a similar manner from $6.17 \pm 0.36 \mathrm{~mm}^{2}$ to $4.9 \pm 0.15 \mathrm{~mm}^{2}(\mathrm{p}<0.01)$. Interestingly, the survival rate improved significantly in the NVP-BEZ235-treated group compared to the control ( $\mathrm{p}<$ 0.0001) (Figure 4F).

\subsection{NVP-BEZ235 considerably reduces the tumor mitotic index and osteosarcoma vascularization without affecting bone microarchitecture parameters}

To better understand the in vivo effects of NVP-BEZ235, histology assessment of tumor tissue was carried out as well as histomorphometry analysis on systemic bone (contralateral 
limb). As tumor growth is driven by numerous factors including neoangiogenesis and its related consequence tumor cell proliferation, we first analyzed the tumor vasculature using CD31 and CD146 immunostaining (Figure 5). Interestingly, $45 \mathrm{mg} / \mathrm{kg} / \mathrm{day}$ of NVP-BEZ235 inhibited both $\mathrm{CD} 146^{+}$and $\mathrm{CD} 31^{+}$cells compared to the control group. This decrease correlated with the slower tumor progression described above. While the tumor mass was composed of numerous $\mathrm{Ki}^{+}$cells in the control mice, NVP-BEZ235-treated tumors were characterized by a marked decrease of the $\mathrm{Ki}^{+} 7^{+}$proliferative tumor cells. Overall, these data demonstrate the anti-angiogenic and anti-proliferative activities of NVP-BEZ235 in osteosarcomas.

Finally, we investigated the effects of NVP-BEZ235 on bone tissue by analyzing $\mu \mathrm{CT}$ parameters and $\mathrm{TRAP}^{+}$and osterix ${ }^{+}$cells. Micro CT investigations did not reveal any marked effect on bone parameters. NVP-BEZ235 did not modify any histomorphometric parameters in the trabecular bone measured on the contralateral limb in $\mathrm{C} 57 \mathrm{Bl} / 6 \mathrm{~J}$ (Supplemental data 3) and nude mice (Supplemental data 4), excepting a slight decrease in cortical thickness in C57Bl/6J and a slight increase in bone surface density (Supplementary Table 3). Surprisingly, histological assessment revealed that NVP-BEZ235 significantly increased the number of $\mathrm{TRAP}^{+}$cells and decreased osterix ${ }^{+}$cells in $\mathrm{C} 57 \mathrm{BL} / 6 \mathrm{~J}$ mice after three weeks of treatment (Figure 6). 


\section{DISCUSSION}

It is widely admitted that the development of bone sarcomas is controlled by the tumor cell environment, called the bone niche. This concept is based on the "seed and soils" theory proposed by Paget in 1887 in which tumor cells ("seeds") are said to colonize receptive foci ("soils"). The soil is composed of extracellular matrix and various cells releasing cytokines and growth factors which activate numerous signaling pathways through their binding to tyrosine kinase receptors (IGF1, PDGFR, etc) or/and kinases associated with other membrane receptors $[9,26]$. The $\mathrm{PI} 3 \mathrm{~K} / \mathrm{mTOR}$ pathway is one of these signaling pathways and regulates many basic biological processes (cell proliferation, survival, migration, glucose metabolism, and nutriment sensors) [11,27]. The PI3K pathway is involved in the proliferation and migration of osteosarcoma cells and appears to induce an anti-apoptotic signal associated with resistance to conventional drugs [23,28-32].

Our work confirms that NVP-BEZ235 inhibits osteosarcoma cell proliferation by inducing a cell cycle arrest in the G0/G1 phase without induction of cell death. We demonstrated the therapeutic value of this dual PI3K/mTOR inhibitor in two murine preclinical models of osteosarcoma, regardless of the immune status of the animals used. The therapeutic benefit was associated with a considerable decrease in $\mathrm{Ki}^{+} 7^{+}$cells and tumor vasculature. Ki67 recognizes a nuclear antigen and the expression of Ki67 varies throughout the cell cycle [33]. These variations appear to reflect de novo synthesis rather than an accumulation of non-degraded proteins. In fact, the Ki67 level, which has a short half-life for this marker, is low during the G1 and early S phase and rises to its peak level in mitosis [34]. As a result, a decrease in Ki67 is directly related to cell proliferation, an observation that is in line with the cell cycle arrest in G0/G1 observed after NVP-BEZ235 treatment and reinforced by its considerable inhibition of $\mathrm{Ki}^{+} 7^{+}$in vivo. 
Most tumor growth requires neoangiogenesis to deliver nutrients and oxygen to the cells, and facilitates the extravasation of cancer cells which can migrate, colonize various organs and therefore form metastases. CD146, inhibited after NVP-BEZ235 treatment in mice with osteosarcomas, has been identified as an endothelial cell adhesion molecule implicated in blood vessel formation and acts as a co-receptor for VEGFR-2 in tumor angiogenesis $[35,36]$. Immunohistochemistry revealed the high expression of CD146 in osteosarcomas related to the high propensity of osteosarcoma cells to stimulate neovessel formation for their own development. Schnell et al. identified endothelial cells as a NVP-BEZ235 target and demonstrated that the drug reduces tumor vasculature by a mechanism guided by PI3K target modulation [37]. The down-modulation of CD146 correlates with the decrease in the platelet endothelial cell adhesion molecule (CD31) and identifies endothelial cells as key targets of dual PI3K/mTOR in osteosarcomas.

We studied the impact of NVP-BEZ235 treatment on the histomorphometric parameters of bone. While $\mu \mathrm{CT}$ analyses did not reveal any major effects of the drug, histologic assessment identified deregulation between osteoclasts and osteoblasts as shown by an increase in the $\mathrm{TRAP}^{+}$cell surface and the down-regulation of osterix ${ }^{+}$cell numbers. This finding may appear somewhat contradictory. However, to date, the role of the PI3K/mTOR pathway in osteogenesis has remained controversial because conflicting studies using mTOR inhibitors have reported both negative and positive effects and their effects are cross-linked to the hormonal status of patients [38]. Similarly, Martin et al. recently reported that NVPBEZ235 promotes human osteogenic differentiation at the same time as a considerable upregulation of Noggin, a BMP antagonist inhibiting in vivo osteogenesis $[39,40]$. This effect appears to be a local feedback mechanism to temper BMP activities. Furthermore, high concentrations of NVP-BEZ235 (> $530 \mathrm{nM})$ totally inhibit the proliferation of osteoblast progenitors in favor of a reduced osteogenesis [39]. Canalis et al. demonstrated that 
osteoblast-specific conditional null Noggin mice had osteopenia and hypothesized a BMPindependent role of Noggin in skeletal homeostasis [41]. In addition, in these mice, the authors showed that osteoclast numbers increased in 1-month-old male Noggin conditional null mice and that bone formation increased in 3-month-old mice. The effect of NVP-BEZ235 may be due to BMP-dependent and independent activities of Noggin after several weeks of administration which remain not fully understood. Additional experiments are required to better understand the long term effect of $\mathrm{PI} 3 \mathrm{~K} / \mathrm{mTOR}$ inhibitors on bone remodeling.

Overall, our data provide evidence that $\mathrm{PI} 3 \mathrm{~K} / \mathrm{mTOR}$ pathway is a potential target for treating osteosarcoma. Due to the lack of apoptotic activity, NVP-BEZ235 is promising as an adjuvant drug for bone sarcomas.

Acknowledgements: Bérengère Gobin received a $\mathrm{PhD}$ fellowship from the Region des Pays de la Loire and INSERM.

Financial support: This work was funded by a Novartis Pharma grant to INSERM UMR957 and by the Ligue Nationale Contre le Cancer. The funders had no role in study design, data collection and analysis, decision to publish, or preparation of the manuscript.

Conflict of interest: The authors have declared that no competing interests exist. 


\section{REFERENCES}

[1] D. Heymann, F. Rédini, Bone sarcomas: pathogenesis and new therapeutic approaches. BoneKey Rep. 8 (2011)402-414.

[2] P. Picci, Osteosarcoma (osteogenic sarcoma), Orphanet J. Rare Dis. 2 (2007)6.

[3] K. Ando, M.F. Heymann, V. Stresing, K. Mori, F. Redini, D. Heymann, Current therapeutic strategy and novel approaches in osteosarcoma. Cancers 5 (2013)591-616.

[4] G. Rosen, M.L. Murphy, A.G. Huvos, M. Gutierrez, R.C. Marcove, Chemotherapy, en bloc resection, and prosthetic bone replacement in treatment of osteogenic sarcoma.Cancer 37 (1976) 1-11.

[5] M.P. Link, A.M. Goorin, M. Horowitz, W.H. Meyer, J. Belasco, A. Baker, A. Vala, J. Shuster, Adjuvant chemotherapy of high-grade osteosarcoma of the extremity. Updated results of the multi-institutional osteosarcoma study. Clin. Orthop. 270 (1991) 8-14.

[6] A.J. Provisor, L.J. Ettinger, J.B. Nachman, M.D. Krailo, J.T. Makley, E.J. Yunis, A.G. Huvos, D.L. Betcher, E.S. Baum, C.T. Kisker, J.S. Miser, Treatment of non-metastatic osteosarcoma of the extremity with pre-operative chemotherapy: a report from the Children's Cancer Group. J. Clin. Oncol. 15 (1997)76-84.

[7] TK. Man, P.H. Rao, C.C. Lau, Genomic and proteomic profiling of osteosarcoma. In: Heymann D, editor. Bone Cancer: progression and therapeutic approaches. Academic Press, 181-192, 2010.

[8] K. Ando, K. Mori, F. Verrecchia, M. Baud'huin, F. Rédini, D. Heymann, Molecular alterations associated with osteosarcoma Development. Sarcoma (2012) 523432.

[9] D. Heymann, F. Rédini, Targeted therapies for bone sarcomas. BoneKey Rep., in press.

[10] B. Ory, G. Moriceau, F. Rédini, D. Heymann, mTOR inhibitors (rapamycin and derivatives) and nitrogen-bisphosphonates: bi-functional compounds for the treatment of bone tumors. Current Med. Chem. 14 (2007)1381-1387. 
[11] B. Vanhaesebroeck, J. Guillermet-Guibert, M. Graupera, B. Bilanges, The emerging mechanisms of isoform-specific PI3K signalling. Nat. Rev. Mol. Cell Biol. 11 (2010) 329341.

[12] O. Vadas, J.E. Burke, X. Zhang, A. Berndt, R.L. Williams, Structural basis for activation and inhibition of class I phosphoinositide 3-kinases. Sci. Signal 4 (2011) re2.

[13] F. Janku, J.J. Wheler, A. Naing, V.M. Stepanek, G.S. Falchook, S. Fu, I. GarridoLaguna, A.M. Tsimberidou, S.A. Piha-Paul, S.L. Moulder, J.J. Lee, R. Luthra, D.S. Hong, R. Kurzrock, PIK3CA mutations in advanced cancers: characteristics and outcomes. Oncotarget 3 (2012) 1566-1575.

[14] S.M. Maira, F. Stauffer, J. Brueggen, P. Furet, C. Schnell, C. Fritsch, S. Brachmann, P. Chène, A. De Pover, K. Schoemaker, D. Fabbro, D. Gabriel, M. Simonen, L. Murphy, P. Finan, W. Sellers, C. García-Echeverría, Identification and characterization of NVPBEZ235, a new orally available dual phosphatidylinositol 3-kinase/mammalian target of rapamycin inhibitor with potent in vivo antitumor activity. Mol. Cancer Ther. 7 (2008) $1851-1863$.

[15] C. Santiskulvong, GE Konecny, M. Fekete, K.Y. Chen, A. Karam, D. Muholland, C. Eng, H. Wu, M. Song, O. Dorigo, Dual targeting of phosphoinositide 3-kinase and mammalian target of rapamycin using NVP-BEZ235 as a novel therapeutic approach in human ovarian carcinoma. Clin. Cancer Res. 17 (2011) 2373-2384.

[16] A.C. Faber, D. Li, Y. Song, M.C. Liang, B.Y. Yeap, R.T. Bronson, E. Lifshits, Z. Chen, S.M. Maira, C. García-Echeverría, K.K. Wong, J.A. Engelman, Differential induction of apoptosis in HER2 and EGFR addicted cancers following PI3K inhibition. Proc. Natl. Acad. Sci. U.S.A. 106 (2009)19503-19508. 
[17] A.P. Bhatt, P.M. Bhende, S.H. Sin, D. Roy, D.P. Dittmer, B. Damania. Dual inhibition of PI3K and mTRO inhibits autocrine and paracrine proliferative loops in PI3K/Akt/mTORaddicted lymphomas. Blood 115 (2010) 4455-4463.

[18] M. Manara, G. Nicoletti, D. Zambelli, S. Ventura, C. Guerzoni, L. Landuzzi, P.L. Lollini, S.M. Maira, C. García-Echeverría, M. Mercuri, P. Picci, K. Scotlandi, NVP-BEZ235 as a new therapeutic option for sarcoma. Clin. Cancer Res. 16 (2010) 530-540.

[19] P. Nanni, G. Nicoletti, L. Landuzzi, S. Croci, A. Murgo, A. Palladini, A. Antognoli, M.L. Lanzano, V. Stivani, V. Grosso, S.M. Maira, C. García-Echeverría, K. Scotlandi, C. De Giovanni, P.L. Lollini, High metastatic efficiency of human sarcoma cells in Rag2/gc double knockout mice provides a powerful test system for antimetastatic targeted therapy. Eur. J. Cancer 46 (2010) 659-668.

[20] B. Klein, S. Pals, R. Masse, J. Lafuma, M. Morin, N. Binart, J.R. Jasmin, C. Jasmin, Studies of bone and soft-tissue tumours induced in rats with radioactive cerium chloride. Int. J. Cancer 20 (1977) 112-119.

[21] K. Kamijo, T. Koshino, M. Uesugi, H. Nitto, T. Saito, Inhibition of lung metastasis of osteosarcoma cell line POS-1 transplanted into mice by thigh ligation. Cancer Lett. 188 (2002)213-219.

[22] M.J. Joliat, S. Umeda, B.L. Lyons, M.A. Lynes, L.D. Shultz, Establishment and characterization of a new osteogenic cell line (MOS-J) from a spontaneous C57BL/6J mouse osteosarcoma. In Vivo 16(2002) 223-228.

[23] G. Moriceau, B. Ory, L. Mitrofan, C. Riganti, F. Blanchard, R. Brion, C. Charrier, S. Battaglia, P. Pilet, M.G. Denis, L.D. Shultz, J. Mönkkönen, F. Rédini, D. Heymann, Zoledronic acid potentiates mTOR inhibition and abolishes the resistance of osteosarcoma 
cells to RAD001 (Everolimus): pivotal role of the prenylation process. Cancer Res. 70 (2010) 10329-10339.

[24] F. Lamoureux, P. Richard, Y. Wittrant, S. Battaglia, P. Pilet, V. Trichet, F. Blanchard, F. Gouin, B. Pitard, D. Heymann, F. Redini, Therapeutic relevance of osteoprotegerin gene therapy in osteosarcoma: blockade of the vicious cycle between tumor cell proliferation and bone resorption. Cancer Res. 67 (2007) 7308-7318.

[25] Y.X. Zhang, J.G. van Oosterwijk, E. Sicinska, S. Moss, S.P. Remillard, T. van Wezel, C. Bühnemann, A.B. Hassan, G.D. Demetri, J.W. Bovée, A.J. Wagner, Functional profiling of receptor tyrosine kinases and downstream signaling in human chondrosarcomas identifies pathways for rational targeted therapy. Clin. Cancer Res. 19 (2013) 3796-3807.

[26] E. David, F. Blanchard, M.F.Heymann, G. De Pinieux, F. Gouin, F. Rédini, D. Heymann, The Bone Niche of Chondrosarcoma: A Sanctuary for Drug Resistance, Tumour Growth and also a Source of New Therapeutic Targets. Sarcoma (2011) 932451.

[27] S. Wullschleger, R. Loewith, M.N. Hall, TOR signaling in growth and metabolism. Cell 124 (2006) 471-484.

[28] B. Fallica, J.S. Maffei, S. Villa, G. Makin, M. Zaman, Alteration of cellular behavior and response to PI3K pathway inhibition by culture in 3D collagen gels. PLoS One 7 (201) e48024.

[29] G. Zhao, C. Cai, T. Yang, X. Qiu, B. Liao, W. Li, Z. Ji, J. Zhao, H. Zhao, M. Guo, Q. Ma, C. Xiao, Q. Fan, B. Ma, MicroRNA-221 induces cell survival and cisplatin resistance through PI3K/Akt pathway in human osteosarcoma. PLoS One 8 (2013) e53906.

[30] K. Wang, Y. Zhuang, C. Liu, Y. Li, Inhibition of c-Met activation sensitizes osteosarcoma cells to cisplatin via suppression of the PI3K-Akt signaling. Arch. Biochem. Biophys. 526 (2012)38-43. 
[31] M. Tsubaki, T. Satou, T. Itoh, M. Imano, M. Ogaki, M. Yanae, S. Nishida, Reduction of metastasis, cell invasion, and adhesion in mouse osteosarcoma by YM529/ONO-5920induced blockade of the Ras/MEK/ERK and Ras/PI3K/Akt pathway. Toxicol. Appl. Pharmacol. 259 (2012) 402-410.

[32] Y. Fukaya, N. Ishiguro, T. Senga, Y. Ichigotani, Y. Sohara, M. Tsutsui, T. Shioura, T. Iwamoto, M. Hamaguchi., A role for PI3K-Akt signaling in pulmonary metastatic nodule formation of the osteosarcoma cell line, LM8. Oncol. Rep. 14 (2005) 847-852.

[33] K. Kontzoglou, V. Palla, G. Karaolanis, I. Karaiskos, I. Alexiou, I. Pateras, K. Konstantoudakis, M. Stamatakos, Correlation between Ki67 and breast cancer prognosis. Oncology 84 (2013)84:219-225.

[34] J.M. Guinebretière, J.C. Sabourin, Ki-67, marker of proliferation. Ann. Pathol. 17(1997) 25-30.

[35] C. Zheng, Y. Qiu, Q. Zeng, Y.Zhang, D. Lu, D. Yang, J. Feng, X. Yan. Endothelial CD146 is required for in vitro tumor-induced angiogenesis: the role of a disulfide bond in signaling and dimerization. Int. J. Biochem. Cell Biol. 41 (2009) 21632172.

[36] T. Jiang, J. Zhuang, H. Duan, Y. Luo, Q. Zeng, K. Fan, H. Yan, D. Lu, Z. Ye, J. Hao, J. Feng, D. Yang, X. Yan, CD146 is a coreceptor for VEGFR-2 in tumor angiogenesis. Blood 120 (2012) 2330-2339.

[37] C.R. Schnell, F. Stauffer, P.R. Allegrini, T. O'Reilly, P.M. McSheehy, C. Dartois, M. Stumm, R. Cozens, A. Littlewood-Evans, C. García-Echeverría, S.M. Maira, Effects of the dual phosphatidylinositol 3-kinase/mammalian target of rapamycin inhibitor NVPBEZ235 on the tumor vasculature: implications for clinical imaging. Cancer Res. 68 (2008) 6598-6607 
[38] P. Hadji, R. Coleman, M. Gnant. Bone effects of mammalian target of rapamycin (mTOR) inhibition with everolimus. Crit. Rev. Oncol. Hematol. 87 (2013) 101-111

[39] S.K. Martin, S. Fittre, L.F. Bon, J.J. Drew, S. Gronthos, P.R. Shepherd, A.C. Zannettino, NVP-235, a dual pan class I PI3K and mTOR inhibitor, promotes osteogenic differentiation in human mesenchymal stromal cells. J. Bone Miner. Res. 25 (2010) 21262137.

[40] R.D. Devlin, Z. Du, R.C. Pereira, R.B. Kimble, A.N. Economides, V. Jorgetti, E. Canalis, Skeletal overexpression of noggin results in osteopenia and reduced bone formation. Endocrinology 144 (2003) 1972-1978.

[41] E. Canalis, L.J. Brunet, K. Parker, S. Zanotti. Conditional inactivation of noggin in the postnatal skeleton causes osteopenia. Endocrinology 153(2012)1616-1626. 


\section{FIGURE LEGENDS}

Figure 1: NVP-BEZ235 decreases the PI3K pathway and consequently the proliferation of human (MG-63, HOS) and murine (MOS-J, POS-1) osteosarcoma cells. HOS and MOS-J cells were cultured with or without increasing doses of NVP-BEZ235 (chemical structure in A, see ref. 14) for 1 to 24h. (B) Kinetic effect of $200 \mathrm{nM}$ of NVP-BZ235 in HOS and MOS-J cells. (C) Dose-ranging experiment from 50 to $1000 \mathrm{nM}$ of NVP-BEZ235 in osteosarcoma cells treated for 3 hours. XTT assay on human (D) and murine (E) cells treated with increasing doses of NVP-BEZ235 for 72 hours. Data are presented as the percentage of untreated control cells and are expressed as the mean \pm SD of 3 independent experiments.

Figure 2: NVP-BEZ235 induces a cell cycle arrest of osteosarcoma cells in the G0/G1 phase with no cell death. Human (A) and murine (B) osteosarcoma cells were treated with $200 \mathrm{nM}$ of NVP-BEZ235 or vehicle (CT) for 24 hours before DNA labeling by propidium iodide and cell cycle analysis by flow cytometry. Caspase activity assay in a time course experiment with $200 \mathrm{nM}$ of NVP-BEZ235 analyzed in human HOS (C) and murine MOS-J (D) osteosarcoma cell lines. STS (Staurosporin) was used as the positive control. All experiments were repeated 3 times, and representative results are shown.

Figure 3: NVP-BEZ235 inhibits the growth of murine MOS-J osteosarcoma in vivo. $\mathrm{C} 57 \mathrm{Bl} / 6 \mathrm{~J}$ with MOS-J tumors ( $\mathrm{n}=8$ per group) were assigned as controls (vehicles) or to NVP-BEZ235 (45 mg/kg/day). Tumor volumes were calculated by measuring two perpendicular diameters using calipers as described in the Materials and Methods section (A). Follow-up of tumor progressions between days 5 and 22 (B). Representative $\mu$ CT images of ectopic tumor bone (red) (C). MicroCT analysis of ectopic tumor bone $\left[\mathrm{BS}\left(\mathrm{mm}^{2}\right), \mathrm{BV}\right.$ 
$\left.\left(\mathrm{mm}^{3}\right)\right]$ on explanted bones. Results are presented as a mean $\pm \operatorname{SEM}(\mathbf{D}) . * * \mathrm{P}<0.01 ; * * * \mathrm{P}<$ 0.001 compared to the control (CT).

Figure 4: NVP-BEZ235 slows down the progression of human HOS osteosarcoma, reduces ectopic tumor bone formation and improves animal survival. Nude mice with HOS tumors ( $\mathrm{n}=8$ per group) were assigned as controls (vehicles) or to NVP-BEZ235 (45 $\mathrm{mg} / \mathrm{kg} /$ day) (A). Follow-up of tumor progression between days 5 and 22 (B). Representative $\mu \mathrm{CT}$ images of the ectopic tumor bone (red) with or without NVP-BEZ235 (C). Micro CT analysis of ectopic tumor bone $\left[\mathrm{BS}\left(\mathrm{mm}^{2}\right), \mathrm{BV}\left(\mathrm{mm}^{3}\right)\right]$ on explanted bones (D).Animal survival after NVP-BEZ235 therapy for 40 days (E). Results are presented as a mean \pm SEM. ** $\mathrm{P}<0.01$ compared to the control (CT).

Figure 5: NVP-BEZ235 reduces osteosarcoma vascularization and associated tumor cell proliferation in vivo. $\mathrm{C} 57 \mathrm{Bl} / 6 \mathrm{~J}$ with MOS-J tumors ( $\mathrm{n}=6$ per group) were assigned as controls (vehicles) or to NVP-BEZ235 $(45 \mathrm{mg} / \mathrm{kg} /$ day). The treatment started 1 day after tumor cell implantation and was continued for three weeks. Tumor vascularization was studied by following the positive expression of CD31 and CD146 by means of immunohistochemistry. Tumor cell proliferation was determined using $\mathrm{Ki}^{+}$ immunostaining. Bar: $250 \mu \mathrm{m}$ (CD146, Ki67), $100 \mu \mathrm{m}$ (CD31).

Figure 6: Histomorpometric markers after 21 days of NVP-BEZ235 administration. TRAP $^{+}$and osterix ${ }^{+}$cells were evaluated by means of immunohistochemistry and histoenzymatic analysis respectively in the non-tumor limbs of C57BL/6J. Specimens were 
scored and estimated in terms of the number of positive cells \pm SD for osterix and the surface occupied by osteoclasts determined by Image $\mathrm{J}$ in the delimited ROI. * $\mathrm{P}<0.05$; *** $\mathrm{P}<$ 0.001 compared to the control. Bar: $250 \mu \mathrm{m}$ all panels except for TRAP bone cortical views (bar $100 \mu \mathrm{m})$. 